\title{
In defence of the Children Act
}

In a recent issue of ADC (2000;82:192-6), we published a paper by Speight and Wynne expresssing their concern about certain aspects of child protection procedures in the UK. This month we published a response by the Rt Hon Lady Fustice Hale (formerly Professor Brenda Hoggett QC), who was the Law Commissioner in charge of the programme of reform in family law from 1984-93. She was also a member of the interdepartmental review of the Child Care Law published in 1985, which led to the 1989 Act. A bill that led to this Act was drafted mainly at the Law Commission before it became a government bill during 1998-9.

Dame Brenda Hale is now a High Court fudge sitting in the family division, where she has ample opportunities to experience the Children Act in practice. She is currently a member of the Court of Appeal.

It was with sadness and concern that I read the recent article by Nigel Speight and Jane Wynne, as I have great respect for their work as paediatricians. ${ }^{1}$ The sadness was that "physicians committed to logical thought and evidence based practice" should have gone into print without, it seems, having checked some basic facts or having read and understood the Children Act 1989 which they criticise so severely. The concern is that if their "anecdotal, impressionistic and subjective" comments reflect a real experience of practice under the Act, then others must have similarly misunderstood and misapplied its basic principles.

In the discussion of the background to the Children Act, Speight and Wynne comment that the authors of the Act seem to have been more influenced by lobbying from parents' rights groups and that "at no stage during the drafting of the Children Act does there appear to have been any counterbalancing input from a lobby for the rights of abused children." Many of us who took part in the preparation of the Act will find that offensive. It is also incorrect. The Children Act was the product of an extensive programme of consultation. The Interdepartmental Review of Child Care Law was established in 1984 in response to the Report of the House of Commons Social Services Committee on Children in Care. ${ }^{2}$ Twelve consultation papers were produced by the Department of Health and Social Security and comments were received from a great many interested bodies and individuals. The terrible death of Jasmine Beckford ${ }^{3}$ was then at the forefront of everyone's mind. The review was published as a Consultation Document in $1985^{4}$ but its principles and recommendations survived largely unchanged in the Children Act. Many comments were received on the review. There were also the further well publi- cised tragedies of Kimberley Carlile, Heidi Koseda, and Tyra Henry. ${ }^{5-7}$ These sources resulted eventually in the government's White Paper, published in 1987, before the Cleveland crisis arose. ${ }^{8}$ The Cleveland crisis may have been the catalyst which persuaded the government of the need for legislation, but it did not result in any substantial changes, and the previous recommendations were endorsed by the inquiry report. ${ }^{9}$ This was the result of a very thorough investigation chaired by Dame Elizabeth Butler-Sloss, who is now President of the Family Division, with the assistance of both social work and paediatric assessors.

In their section entitled Defects of the Children Act, the authors quote the initial guidance on the Act, which states that the Act rests on the principle that "children are generally best looked after within the family with both parents playing a full part and without resort to legal proceedings" ${ }^{10}$ They accept that this would be an unexceptionable aim in an ideal society where child abuse and neglect do not exist. They may have forgotten that the Act is concerned with all children, and not just the abused and neglected. One of the Act's main aims was to integrate all the law relating to the upbringing of children, including disabled children. Any civilised society has to start from the proposition that children are best brought up in their own families: it is the bedrock of society that children belong in families and not to the state.

But that is only the starting point. The Act sets a threshold for compulsory state intervention in family life which is more precise but wider than that of the Children and Young Persons Act 1969 and the Child Care Act 1980. As Speight and Wynne acknowledge, it allows for intervention on the basis of future as well as actual harm. Furthermore, such harm need only be a serious possibility (rather than a probability) to pass the test.

Speight and Wynne also argue that "in every case of significant abuse and neglect it should be a completely open question as to what is in the child's best interests". The Act provides a framework for this; courts cannot make care and supervision orders unless the child is suffering or likely to suffer significant harm (section 31(2)), but once this has been shown, the welfare of the child is the court's paramount concern (section 1(1)). The Act lays down a series of relevant factors for the court to consider in order to decide what will be best for the child (section 1(3)), but the only value judgment as to what will be best is that delay is likely to be detrimental (section 1(2)). As the welfare principle is highlighted at the beginning 
of the Act (section 1(1)), it is wrong of Speight and Wynne to assert that "the Act has already stated that in general children should be kept in their natural families so there is no escape from the closed loop".

The Act does impose a general duty upon local social services authorities "to safeguard and promote the welfare of children within their area who are in need", and "so far as is consistent with that duty, to promote the upbringing of such children by their families" (section 17(1)). The local authorities are required to take reasonable steps to protect children from abuse and neglect and to reduce the need to bring children into care and to expose them to other proceedings (schedule 2, paras 4 and 7). But where the authorities have reasonable cause to suspect that a child in their area is suffering, or is likely to suffer, significant harm, they have a specific duty to make inquiries, which will enable them to decide whether to take action to protect the child and, if necessary, to act (sections 47(1) and (8)). These duties are couched in somewhat stronger terms than the previous duties in the Children and Young Persons Act 1969 (sections 2(1) and (2)).

When discussing the concept of partnership, Speight and Wynne may be forgiven for failing to realise that this is not expressed in the Act; it is certainly an underlying principle, but is one of working together in the interests of the child. It is also important to distinguish between the decision making process and the decisions themselves. It is only fair that parents should be appropriately involved in any decision making processes that concern their children and which may fundamentally affect their relationships. However, nowhere does the Act require that parents dictate what those decisions should be.

The authors' accusation that the Act "is trivialising child abuse by decriminalising it" is incomprehensible. The Act has nothing to do with criminal prosecutions for offences against children and does nothing to render those offences less serious or to reduce the chances of prosecution. Yet this was, of course, a point seized upon when Speight and Wynne's article was reported in the media.

The authors also argue that parents who have failed in their discharge of parental responsibility should lose some, if not all, their rights. Again, this is exactly what the act provides: if a local authority shares parental responsibility under a care order, the local authority can decide "the extent to which a parent ... may meet his parental responsibility, as long as they are satisfied that it this is necessary to safeguard or promote the child's welfare" (sections 33(3) and (4)). The authors suspect some connection with the Child Support Act, which was passed two years after the Children Act, and had not been conceived (as far as I know) when the Children Act was under discussion, and was the product of a very different political and parliamentary process.

The Act has not abandoned the terminology of "care". Neglected or abused children are still the subject of care proceedings, in which care orders are made, which result in their being "in care". The aim was to emphasise the parental responsibilities undertaken by the local authority, and to draw a sharper distinction between these children and - for example, disabled or refugee children, for whom the local authority provides accommodation or other services without any compulsory intervention.

This is just one illustration of the underlying balance that the Act tried to strike. The authors postulate "a young child ... subject to severe abuse or neglect by severely damaged parents" in whom "the prospects for constructive change are small" and where "the quality of care within the extended family leaves much to be desired". The Act was designed to improve rather than to reduce the protection available to such children, drawing a clear distinction between them and the great majority of children who have not been subject to severe abuse or neglect, who will be better off at home but who may need some help from social services, or who will be better off with their extended family with appropriate help and support.

It is equally unjust to blame the Act for raising the threshold of proof of abuse. The Act states that the court must be "satisfied" that the child is suffering or is likely to suffer significant harm. The standard of proof is the product of judicial decision making at the highest level. For some time, there was a tendency to suggest that the more serious the allegation, the higher the standard, although this was never as high as "beyond reasonable doubt". But the House of Lords, the highest court in the United Kingdom, decided that the standard of proof was always the balance of probabilities (as Speight and Wynne say that it should be).$^{11}$ It also said that some things are inherently less likely to have happened and therefore may require more cogent evidence to arrive at the conclusion that, on balance, they have occurred. I have heard paediatricians make similar observations about rare occurrences.

The real problem is quite different: what to do about the case where you cannot be satisfied, even on the balance of probabilities, that abuse or neglect took place, but you remain uneasy about the situation and believe that the child may be at risk in the future? Would this be an acceptable basis for separating that child from his family? And can you continue to believe that the child should be separated from its family if your only reason for doing so is that while you are not convinced that abuse has taken place, you cannot be sure that it hasn't? The House of Lords was divided three to two on the latter point, but the majority thought that you could not support such a belief. Many family lawyers disagree.

No one pretends that such decisions are easy to make or that the decision makers, whether social workers, doctors, or courts, always get it right: but the Act itself is not to blame. Let us consider the case studies reported in the article.

Case 2 concerned the problems faced by relatives of a child's mother, who sought custody of the child after the mother had com- 
mitted suicide because of prolonged sadistic marital violence. The difficulties faced by the relatives in obtaining custody of the child are not the fault of the Act: the Act reduced their problems by making it possible for such relatives to apply for residence orders when previously the child would have been made a ward of court (at great expense and with even greater delays). The real accusations should be levied elsewhere: at the reluctance of courts and professionals to acknowledge domestic violence and to recognise the effects upon the child of violence towards the mother. That has nothing to do with the Act: indeed, the Act sought to replace some of the assumptions about what was best for children with a more objective range of factors, only to find that the courts and others reimposed those earlier assumptions. These situations are now being taken much more seriously, and recent legal decisions reflect this, as has the recent report from the Children Act Sub-Committee of the Lord Chancellor's Advisory Board on Family Law on Contact and Domestic Violence. ${ }^{12}$

Case 3 complains that an adoption plan for a child, who had been in foster care for four years while rehabilitation proved impossible, was changed without proper assessment, shortly after the Children Act came into force. That is not the fault of the Act but of faulty assessments and drift.

Case 4 concerned a little girl who was failing to thrive and who had signs highly suggestive of penetrative anal abuse, but who was left in the family home for six months. This resembles a case I encountered where the inaction had nothing to do with the Act but rather with industrial action taken in protest at lack of resources.

Case 5 concerned a boy of 15 who did not want to go home from hospital but whose social workers were unsympathetic. However, a paediatrician put him in touch with a solicitor who acted for him and forced the local authority to help. It is the Children Act itself which made this possible, by recognising that children may take action in their own right. Ironically, this caused something of a furore when social workers were accused of helping children to defy their parents or run away from home.

No one can argue that everything in the garden is rosy. Let us acknowledge the real problems in such cases:

- Social workers are a hard pressed and underfunded profession who have to make difficult judgments without any of the protection traditionally afforded to doctors and lawyers. They are damned by the press if they intervene too soon or too often, and damned if they intervene too little or too late. They are subject to varying guidance from the government or their superiors as to where their energies should be channelled. There is a risk that their expertise in assessment will be undervalued by courts and others, thus contributing to their own lack of confidence and to delay and expense in the courts.

- In a society governed by the rule of law (to say nothing of the European Convention on Human Rights), compulsory interven- tion in the lives of children and their parents must be authorised by a court after due process of law. It is not and should not be open to social workers, doctors, teachers, or anyone else simply to decree that a child should be removed into public care or adopted into another family. In several respects, procedures before the Children Act were condemned by the European Court of Human Rights and needed to be amended.

- The delay and expense of court proceedings are a great concern. For the past nine years, the legal profession has been trying to operate effective case management to reduce delays but has not succeeded. This is amply illustrated by case 1 , where it took 15 months to obtain a care order for a baby fostered at birth, with a plan for adoption. But the problem is recognised and we keep on trying to tackle it. Before the Children Act, the delays in wardship were at least as bad but were not systematically counted. There is a special need to provide a fast but effective service for very young children

- Some see it as a problem that the higher courts have lost their power to put children in care without the local authority's consent, and to give directions to local authorities on how to look after the children. In practice, courts could only give directions to the local authorities in the very broadest terms and there was little scrutiny or sanction for non-compliance. The courts can scrutinise a care plan but they cannot write it or see that is is put into effect, any more than they can force a doctor or a health authority to provide a particular treatment or programme of care for a patient, even if it is clear that it is needed. Do we really think that it would give them power to do so?

- There are serious difficulties and delays in finding appropriate permanent placements for children. Fewer people want to foster, people prepared to adopt may want a different child, and residential placements are both hugely expensive and potentially dangerous. There are organisational issues: transferring responsibility from large national adoption societies to local authorities may not have helped; setting up small unitary authorities may have increased the problems. Adoption procedures also need to be improved (how about implementing the 1992 Adoption Law Review rather than reinventing the wheel?).

We can all benefit from acknowledging how difficult child care practice and decision making is, recognising when we have got it wrong, and trying to learn from those mistakes to do it better next time. It is us, not the Act, who are to blame if seriously abused children are not receiving the protection they deserve.

Royal Courts of fustice, Strand,

DAME BRENDA HALE London WC2A $2 L L$, UK 
1 Speight N, Wynne J. Is the Children Act failing severely abused and neglected children? Arch Dis Child 2000;82:192-6.

2 1993-94 HC 360. London: HMSO

3 A Child in Trust. The Report of the Panel of Inquiry into the circumstances surrounding the death of fasmine Beckford. London: Brent Council, 1985.

4 Department of Health and Social Security. Review of Child Care Law. Report to Ministers of an Interdepartmental Working Party. London: HMSO, 1985.

5 A Child in Mind. The Report of a Commission of Inquiry into the circumstances surrounding the death of Kimberley Carlile. London: London Borough of Greenwich.

6 Report of the Review Panel into the death of Heidi Koseda. London: London Borough of Hillingdon, 1986

7 Whose Child? The Report of the Public Inquiry into the death of Tyra Henry. London: London Borough of Lambeth, 1987.

8 The Law on Child Care and Family Services, Cm 62. London: HMSO, 1987.

9 Report of the Inquiry into Child Abuse in Cleveland 1987, Cm 412. London: HMSO, 1988.

10 An Introduction to the Children Act 1989. London: HMSO, 1989.

11 Re H (Minors) (Sexual Abuse: Standard of Proof) [1996]. Appeal Cases 563.

12 Children Act Sub-Committee of the Lord Chancellor's Advisory Board. On Family Law, Contact and Domestic Violence. London: Lord Chancellor's Department, 2000.

\section{Speight and Wynne's response}

We invited Doctors Speight and Wynne to respond... We are honoured that Dame Brenda Hale has responded to our article in such detail, and thank her for her kind introductory words. We had intended to stimulate debate and wholeheartedly welcome her response. Overall, we feel a sense of common purpose with much of her article and do not wish to be unduly defensive.

We entirely accept Lady Justice Hale's factual rebuttal regarding the sequence of events leading up to the Act to the effect that there was an extensive process of consultation before the Act and, indeed, before the Cleveland crisis. However, we do not regard the mere occurrence of consultation as a counter argument to our statement that at present there is no effective lobby for the rights of abused children in this country. We made no criticism of the Butler-Sloss report which in our view, provided valuable evidence that the one sided media view of Cleveland was misguided. ${ }^{1}$ Unfortunately, the media failed by and large to acknowledge these truths and the public were thereby denied the obligation to think again. We also accept (and indeed stated) that the Children Act as it stands could, and perhaps should, have been a valuable instrument to protect abused children and promote their interests. However, we do not retract our basic assertion (admittedly impressionistic) that the way in which the Act is being interpreted by social workers and the courts frequently fails children. In other words, Hale is justified in feeling "sadness and concern".

In our view, the central issue is the question of what the Act says or doesn't say about natural families. We still believe that the Act's initial guidance on this subject is the cause of all the problems, and that its authors share some responsibility for this. We believe that the unqualified statement that "children are generally best looked after within the family...." was positively dangerous in an Act that deals with abuse and neglect, whichever section it is in.

We stand by everything we wrote regarding the bias in the Act towards natural families and the reinvention of the blood link. If this bias was not intended by the authors of the Act then perhaps there should be an official announcement to this effect.

We entirely endorse Hale's humane and understanding description of the plight of the social work profession. We would suggest that the profession was left unprotected and vulnerable after the Cleveland crisis and thus was more prone to interpreting the Act in favour of natural families.

Where the question of evidence arises, both sides of this debate are equally poorly equipped. Apart from the crude figures for the reduction in care orders that we quoted, very few figures are available. Despite the vital nature of this area of work, there have been no attempts to audit the following important areas:

- how often children with suspicious bruises are not taken to a paediatrician

- the number of cases of abuse when it is decided not to call a child protection case conference

- how often local authority lawyers advise social services that the grounds for care proceedings are not strong enough

- how many times health visitors and teachers are discouraged by the failure of their attempts to activate child protection proceedings

- the number of sexually abused children in school who refrain from disclosing their abuse to teachers because they sense that they will not be adequately protected by the system

- the number of times the courts reject applications for care orders.

Our direct clinical experience of all the above events occurring frequently is what led us to take the position we did in our article.

We do have evidence that delays in Court proceedings are getting worse. ${ }^{2}$ Between 1993 and 1996, the length of proceedings increased from 21 weeks to 29 weeks in Magistrates' courts; from 30 weeks to 50 weeks in County courts; and from 34 weeks to 64 weeks in the High Court. Delays are often due to poor court management and lack of court time. Furthermore, an increasing number of experts are being called and the courts are demanding more thorough assessments. $^{2}$ The Children Act has failed to reverse the adversarial nature of court proceedings, and judges still allow aggressive and hostile cross examination of witnesses and child victims of abuse, to an extent that is a deterrent to the initiation of proceedings.

In general, we have received remarkably little direct feedback on our article. A few paediatricians have commended us; others, together with social services, have maintained a deafening silence. However, one senior social worker in charge of child protection wrote that she had had an uncanny feeling as she read our article that she had already written it herself, 
word for word. She was planning to copy it to all her team and use it as the basis for a series of workshops.

Ultimately, we strongly endorse Lady Justice Hale's final paragraph and hope that the debate continues.
Department of Paediatrics,

Dryburn Hospital,

Durham DH1 5TW, UK

NIGEL SPEIGHT JANE WYNNE

1 Butler-Sloss E. Report of the Inquiry into Child Abuse in Cleveland 1987. London: HMSO, 1988.

2 Buckett C. Waiting for court decisions. Adoption and Fostering 2000;24:55-62.

\section{STAMPS IN PAEDIATRICS}

\section{Congresses}
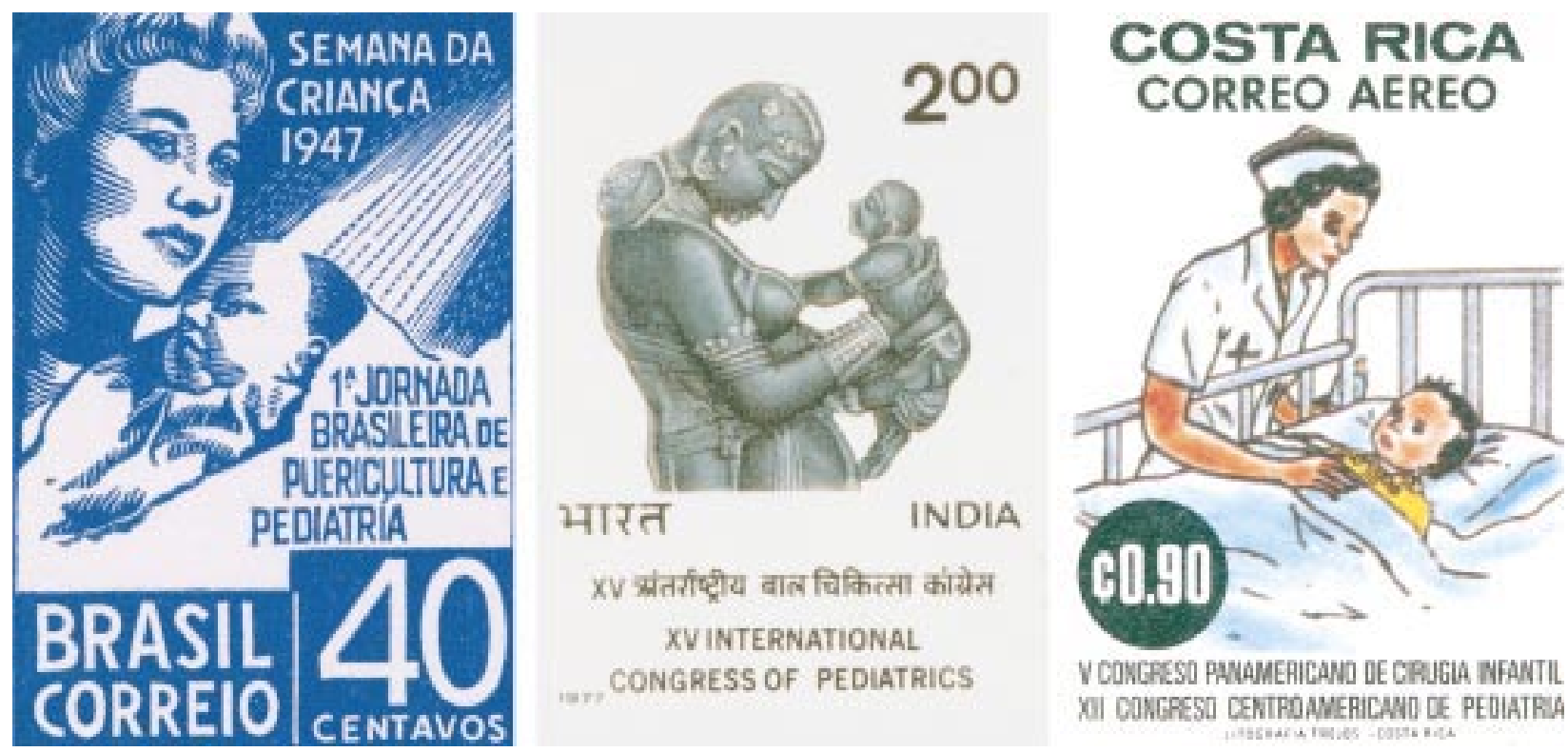

V CONCRESO PANAMERICANO DE CRUGIA NFANTIL. XOI CONGRESI DENTRDANERICWND CE PEDIATRIA

National and international medical meetings are occasionally marked by the release of a stamp from the host country, and a few stamps have appeared over the years to commemorate paediatric congresses. One of the earliest is from Brazil for the 1st Brazilian Infant Welfare Convention and Paediatrics in 1947. In 1977, India released a single stamp to commemorate the 15th International Congress of Paediatrics held in New Delhi, the stamp depicting a Khajuraho sculpture "Mother and Child". Two congresses are shown on the 1976 air stamp from Costa Rica - the 5th Pan American Children's Surgery Congress and the 12th Central American Congress of Paediatrics.

M K DAVIES

A J MAYNE 